\title{
Investigating Factors that Influence SME's Choice of Services Rendered by Microfinance Institutions: Evidence from La-Nkwantanang Municipality in Ghana
}

\author{
Ebenezer Appiah ${ }^{1}$, Deborah Darko Ampeah ${ }^{2} \&$ Wonder Agbenyo ${ }^{3}$ \\ ${ }^{1}$ Research Institute of Economics and Management, Southwestern University of Finance and Economics, \\ Chengdu, China \\ ${ }^{2}$ School of Management and Economics, University of Electronic Science and Technology of China, Chengdu \\ ${ }^{3}$ College of Economics, Sichuan Agricultural University, Chengdu, China \\ Corresponding Author: Wonder Agbenyo, College of Economicss, Sichuan Agricultural University, Chengdu \\ 611130, China. Tel: 86-157-0847-6521.E-mail: agbenyowonder@gmail.com
}

Received: November 21, 2018

Accepted: December 25, 2018

Online Published: January 10, 2019

doi:10.5539/ijef.v11n2p98

URL: https://doi.org/10.5539/ijef.v11n2p98

\begin{abstract}
There is a recent wave of collapsing Microfinance Institution's in Ghana which causes SMEs to think critically about the MFI's they choose to bank with. This has given birth to the investigation of factors that influence SMEs choice of services rendered by microfinance institutions in Ghana. The study adopted the descriptive research design. Stratified random sampling technique was used to select the SMEs for this study and data was collected from a sample of 384 using questionnaires and 279 were returned. The study revealed that electronic banking, convenience and security influences, reputation and legal regulation, interest rate and service provided by the microfinance institution are essential factors that influence the choice of SMEs. The study concludes that the reputation of a business is also essential to its survival, the trust and confidence of the SME can have a direct and profound effect on microfinance institutions. The study recommended that, microfinance institutions should make it a must to obtain all necessary banking licenses from Bank of Ghana before they commence business in order to avoid the embodiment of fear of collapse into potential SME's who might be willing to transact business with them and also educate those who render services on behalf of the bank. Customer service is very important and should be considered as the first priority of the bank.
\end{abstract}

Keywords: small and medium scale enterprises, bank choice, micro-finance institutions and Ghana

\section{Introducation}

Microfinance is unique among development interventions in all countries particularly in developing countries like Ghana (Yunus, 2003). According to Simanowitz and Brody (2004), microfinance is a key technique in achieving the Sustainable Development Goals (SDGs) and in building worldwide economic frameworks that address the issues of the poorest individuals. Microfinance has expanded rapidly in Ghana since the beginning of the present decade, increasing by 20-30 per cent every year. Microfinance institutions have grown step by step throughout the years into three primary categories- formal suppliers, for example, savings and loans companies; semi-formal suppliers, for example, credit unions; and informal suppliers, for example, Susu collectors (Asiama \& Osei, 2007).

Small and Medium scale Enterprises (SMEs) is imperative to economic growth and significantly essential to generate employment (Harvie \& Lee, 2005). According to Harvie and Lee (2005), 70\% of new employment creation in Southeast Asia are guaranteed to originate from SMEs and more than half of the workforce within the private sector in the region. The Ghanaian economy comprises of very small individual businesses, small and medium scale enterprises (SMEs), corporate bodies and multinational organizations. The vital role of these SME's is supported by various MFI's in the country. The notion that agriculture is the lifeblood of any economy is equally attributed to MFI's and SME's. It is undisputable fact that SME's cannot do without MFI's and vice versa. Some key factors of microfinance in Ghana are mostly determined by client satisfaction, thus proximity, service quality, information technology, security, among others. Customer satisfaction is perceived as a psychological state (feeling) appearing after buying and consuming a product or service. Satisfaction is a 
short-term attitude that can readily change given a constellation of circumstances. All microfinance companies in Ghana are competing for market share and as such meeting customer's satisfaction will have a great significance for the future of these institutions.

Several scholars with different methods tried to analyze factors that affect customers' preference in banking services. Among these studies include Mokhlis et al. (2008) who examined the determinants of bank selection criterion in Malaysia considering undergraduate students and African (Blankson et al., 2007; Maiyaki, 2011) countries on the subject of bank selection standards in relation to customers' preference: why and how they hand-picked a particular bank to be obliged to. The literature on factors that influence the choice of financial institutions is disproportionately centered on banks. Similarly, microfinance institutions have become an area of interest to researchers. There is also a recent wave of collapsing MFI's in Ghana which causes SME's to think critically about the MFI's they choose. This paper attempt to bridge the gaps observed in the body of knowledge by examining the factors that influence the choices of SMEs in their selection of microfinance in order to help invent tailored products, processes and customer-oriented approaches geared towards attracting clients and also maintaining old customers.

\section{Review of Related Literature}

This section reviews related literature to the aforementioned topic. The section discusses reviews of existing theoretical and empirical literature relating to the study. The theoretical literature aspect of this paper basically focused on some factors that influence SME's choice of MFI's. The empirical literature, on the other hand, provides previous research works or studies of other researchers that relate to the study.

\subsection{Factors that Influence SME's Choice of Services Rendered by Microfinance Institutions}

Reputation: Many economic theories have facilitated in confirming the importance of reputation in the strategic processes of an organization, but the resources based-view (Barney, 1991) demonstrations the capability of this intangible resource to generate superior profits, and a key sustainable competitive advantage for corporate success. Following this theory, reputations, as indicators of quality of the set of managerial actions, are a valuable resource hard to imitate, which plays a crucial role in times of crisis (Coombs, 2007). Good corporate reputations provide a reservoir of goodwill which safeguards companies from a market failure in times of uncertainty and economic turmoil (Jones et al., 2000). This paper climaxes the fact that a well-integrated application of technology and staff aids to size customer loyalties by creating deeper and fuller customer relations. Based on the theory, reputation was considered as a factor that influences SME's choice of Micro-finance institutions in the municipality.

Convenience: Convenience is defined in different ways according to various authors, but in simple understanding, convenience refers to the location of the bank. Okoe, Osarenkhoe, and Hinson (2013) indicated that convenience is one of the factors which influence the decision of customers when selecting a microfinance institution. When a microfinance has convenience location it will give it the advantage to lord over its competitors who do not have convenience location to their clients. But, according to Zineldin (1996) who stated that, convenient location of microfinance might not influence the decision of choosing a microfinance by customers that much for the reason being that customers who are embraced with technology can do their payment via different methods such as debit card, online banking, credit cards and mobile banking. Based on the contradiction between the scholars this paper considered convenience as a factor that influences SME's choice of Micro-finance institutions.

Service Quality: Some customers of microfinance generally consider lower interest rate as less important than service attributes of efficiency, polite and friendly staff, and pace of transaction (Maiyaki, 2011). Nguyen and LeBlanc (1998) revealed that service quality of a microfinance is the single and most significant factors that will affect the decision of selecting a microfinance by customers. However, Gerrard and Cunningham (2004) claim that even sometimes a bank offering a wider range of product services does not necessarily influence the result of a customer selecting a bank because some customers would like to become multiple bank users rather than single bank users. The contradiction between the scholars lures the study to measured service quality as a factor that influences SME's choice of Micro-finance institutions.

Information Technology: Technology refers to the modern life information technology that characterized by ever-changing evolution to assists and develops a better financial activity in the banking industry. Khawaja and Manarvi (2009) found out that financial institutions such as microfinance which uses technology in its operations reduce the burden on manual input on registers and ledgers with customers that were served through cheques and pay orders, with the introduction of Automatic Teller Machines (ATMs) for interacting with consumers and provide better services. Suganthi (2001), and Idowu et al. (2002), concluded that these improvements have 
positively affected the growth of the entire banking and finance industry. It seems apparent that technological innovation affects not just banking and financial services, but also the direction of an economy and its capacity for continued growth. hence need to be considered a factor that influences the choice of MFI's.

Price of Product and Services: Fees are being charged for the services and apply interest charges on loan, as well as paying interest on certain accounts which creates a wider meaning for pricing in the banking industry (Gerrad \& Cunningham, 2004). Customers normally want to have the best product and services at the lowest price from the financial institution. They would compare prices, cost or benefits of microfinance that offers the similar products and services and opt for the microfinance that they perceive to provide them higher benefits with low cost which meets their preferences (Aregbeyen, 2011). This is why the price of products and service is found to be an important factor for a customer in their microfinance selections, as customers expect and willing to pay the price for the better product and services quality for it (Mabin \& Balderstone, 2003). This factor was therefore considered to assist the researchers to investigate if the prices of products is actually a factor that influences SMEs choice of Micro-finance institutions.

Security: There are some basic things that customers will consider when choosing a microfinance. In order to make a customer have a strong sense of feeling towards the operation of the microfinance, the microfinance has to ensure that trust is one of its hall marks in the finance circle because trust is a key that bridges the relationship of the microfinance and the customers. Some researchers emphasize that trust is very vital in a relationship. When a microfinance security is secured, it will gain the confidence and trust of the customers. Okoe, Osarenkhoe, and Hinson (2013), also found that there is a positive relationship between bank security and the decision to select a financial institution by customers. This factor was therefore considered to investigate if security is actually a factor that influences SME's choice of Micro-finance institutions.

\subsection{Recent Empirical Reviews}

In Ghana, Owusu-Frimpong (1999) has conducted a survey on patronage behaviour of bank customers using an informal telephone interview with six senior bank managers. Findings from 225 respondents discovered that convenient location and friendly employees are the most important attributes determining the image of the banks for their selection decision pursued by the size of the bank and profit-minded services.

In Singapore, Phuong and Yin (2000) undertook a study on bank selection decision in Singapore using the analytical hierarchy process (AHP) to access the principal decision factors used and their relative determinant in bank section decisions. They disclosed that outcomes of the analysis for the total sample specified that the bank selection choice method is based primarily on nine elements. Thus, high-interest rate, appropriate location, and quality of service, self-banking facilities, low charges, low-loan rates, long operating hours, undergraduate privileges and recommendations.

According to the study of Khan et al. (2007), an investigation on 100 customers of Islamic bank customers in Bangladesh, religious principles is the key bank selection criterion of the Islamic bank clients, while clients' demography plays some vital role in defining which selection criteria matter more than others. Furthermore, discoveries for the relationship among bank selection criteria and level of income displays that the choices of 'family and friends' and convenient location depend significantly (at 5\% level) on the level of income.

Rehman and Ahmed (2008) in their study conducted in the city of Lahore (Pakistan) found that the four most important variables influencing customers' choice in selecting a bank were customer services, convenience, online banking facilities and general banking environment. Availability of internet banking was also found to be an imperative bank selection factor.

Mokhlis et al. (2008) also sampled 350 undergraduate students in Malaysia to categorize factors which affect their bank selection decisions and to study whether undergraduates constitute a homogeneous group in relation to the way they select a bank. With "factor analysis" they discovered that undergraduates secure feelings were the most significant factor in inducing the students in selecting a bank. ATM service was the second ranked factor followed by financial benefits. The next three criteria, ranked fourth, fifth and sixth, respectively, were service delivery, nearness and branch location that can be clustered as moderate factors. By contrast, the students considered non-people influential, attractiveness and people influence which were ranked seventh, eighth and ninth respectively did not play significant roles in influencing their decision in selecting the bank. It is interesting to note that their finding also shows the responses did not constitute a homogenous group since gender, stream of study, ethnicity and number of saving accounts held formed different ranked factors in bank selection.

A study conducted by Sanyang et al. (2009) in Gambia on "bank strategic positioning and factors for bank selection" it was discovered that customers highly regard with low service charge and accessibility of ATM 
services to be the most imperative criteria in patronizing banking services. The findings of this study are different from all other studies surveyed so far, in which, low service charge is the most important factor for bank selection decision. His findings also revealed that safety of funds, the speed of transaction and convenient location are also treated as the most important factors in patronizing banking services in Gambia.

A study conducted by Kumar et al. (2009) identified eight determinates- branding, convenience, recommended by peers, required by the company, variety of products and services, rate charges, flexibility in accounts handling and customer-friendly environment are the most important factors affecting the decision of the customers on making the choice of the bank in Malaysia. They recommended that banks need to be innovative in creating more types of channels by riding on technological development; minimizing clients' waiting time and effort ought to be their main priority and objective.

In India, Rao and Sharma (2010) conducted research in the area of student banking focusing on factors that influence their selection of banks. The researchers made use of 312 respondents for the study. The responses were produced by the respondents indicate reliability as a significant choice criterion, which includes employee's courtesy, parking facility, loyalty programs, brand name, security system and low charges with the bank. Additional factors, which have also increase in importance are the responsiveness, value-added services and convenience. Assurance factors, such as speedy services, good rate of interest and zero balance account facility are also significant in importance in motivating the choice of a bank.

A study was conducted by Abduh and Oman (2010) on the Indonesian customer's attitude. This study targeted the customers of Islamic banks. The finding of his study revealed that most customers prefer banks based on announcements of the country's council on interest rates is their first consideration in patronizing a particular bank and puts reason of safety of fund during the financial crisis, has a greater possibility to patronize Islamic banks in Indonesia. Again, marketing and advertisement strategies of bank's also highly influences individuals to patronize Islamic banks.

In Afghanistan, Farooq et al. (2010) studied the section criteria of Islamic customers in patronizing a particular bank. They found that the most important factors leading to the customers' choice for selection of Islamic banking products/services are: religious inclination, a recommendation of family and friends, easy access to branch and profitability of the bank. As the degree of importance of selection criteria of banks is concerned the results shows quite a significance in the educational level and the degree of religious regulations in the selection of banks. The examination of the results revealed that those respondents having graduate degrees in diverse avenues are more influenced by the Islamic teachings and doctrine in selecting a bank in comparison with other respondents having other academic qualification. The results also show that the less educated respondents are comparatively more influenced by friends and family.

A recent study conducted by Katircioglu et al. (2011) investigates the bank selection criteria of undergraduate students who are future potential customers of banks from different regions of the world in a small island economy. They found that availability and convenient location of ATM services, speed and quality of service are the most important factors for considering banks and their services for both Turkish and non-Turkish undergraduate students. Afterwards, they conclude that there are not massive differences in the bank selection factors between Turkish and non-Turkish international students in the case of a state university in North Cyprus.

In Nigeria, Maiyaki (2011) studied on the factors that determine the selection and preference of banks by retail customers. 417 bank customers were used with the help of multi-stage sampling procedure and found that size of bank total asset, has the greatest influence on customer choice of banks, followed by availability of large branch network across the country, the reputation of the bank, personal security of customer, and then convenient access to bank location. On the other hand, recommendations of friends/relatives, the attractiveness of bank's physical structure, the opportunity of telephone banking, availability of assorted retail bank services and reasonable terms of credit/loans repayment were the factors that have the least influence on client choice of banks. Finally, he recommended that banks management should pay attention to factors that have a significant effect on the choice of banks.

Most recently, Singh and Agarwal (2016), research on the important factors that people consider while selecting a bank. They aim to find out whether factors affecting the selection of a commercial bank differ gender-wise and income-wise. The study employed the survey method to gather data from banking clients of Gurgaon with the aid of a standard questionnaire. Factor analysis technique was used for analyzing responses. In order to find out the dominant factors and independent sample t-test and one-way ANOVA to judge the impact of gender and income level of people on these factors. Findings of the study portrayed that fourteen factors eventually influence the selection of a bank and divides all these factors into five different groups on the basis of their 
importance.

\section{Study Methodology}

This section provided the outline of the research methodology adopted. The main discussions in this section include the research design, population of the study, the sample size and sampling technique, data source and collection method. The chapter finally explained the statistical method that was utilized to analyze the data.

\subsection{Research Design}

The study adopted a descriptive research design in order for a thorough analysis of the topic. This method of research was utilized because data was easily collected and questionnaires were answered easily through the issuance of them. According to Mugenda (1999), descriptive research design determines and reports the way things are and also helps a researcher to describe a phenomenon in terms of attitude, values and characteristics.

\subsection{Population and Sample Size of the Study}

The target population was purposely, SME's situated in the regional capital of the Greater Accra region in the La Nkwantanang-Madina Municipality. La Nkwantanang-Madina is situated in the Greater Accra Region. It is one of the 16 Metropolitan, Municipal and District Assemblies in the area and was created in 2012 as a feature of the recently made Assemblies aimed at deepening decentralization and bringing improvement to the doorstep of citizens. Data on the estimated total population of SMEs that operate within the La-Nkwatanang in the Madina Municipality was not readily available. Hence, the study considered the economically active population of a total of 79,841 that constitute the population 15 years or older living in the municipality according to Ghana Statistical Service, 2010 Population and Housing Census. Out of the 79,841, 92.3\% representing $(73,693)$ according to GSS (2010) are economically active. This 73,693 was considered the population for the study. Since the whole population cannot be studied, a sample size was arrived by using the sample size formula provided by Godden (2004) for an infinite population greater than 50,000. From table 3.1 it is evidence that the total population is greater than 50,000 hence making the formula suitable for the calculation of the sample for the study. The formula is explained below and how the sample size was arrived at.

$$
S S=\frac{Z^{2} \times p \times(1-p)}{C^{2}}
$$

Where; SS = sample size; $\mathrm{Z}=\mathrm{Z}$-value (e.g 1.96 for $95 \%$ confidence level); $\mathrm{P}=$ percentage of population picking a choice, expressed in decimal and $\mathrm{C}=$ confidence interval

$$
\begin{gathered}
S S=\frac{(1.96)^{2} \times 0.8 \times(1-0.8)}{0.04^{2}} \\
S S=\frac{3.8416 \times 0.8 \times 0.2}{0.0016}=384.16
\end{gathered}
$$

For the percentage of population picking at a choice, the study considered $80 \%$ with the notion that it comprises of majority of the SME's that operate within the municipality at the time of study. Hence, 384 questionnaires were distributed. However, $73 \%$ of the questionnaire thus 279 of them were return. The study considered the percentage higher enough to proceed.

\subsection{Data Source and Method of Data Collection}

The study was based on primary data to solicit information from SMEs that operate within the La-Nkwatanang in the Madina Municipality. The questionnaire was designed with closed-ended questions which make it easy for analysis. The questionnaire was structured and organized in two sections for the respondents. Section A consist of background information of the respondents and Section B consist of questions regarding factors that influence the choice of SMEs banking specific MFIs and they were measured on 5- point Likert- scale ranging from 1 (strongly agree) to 5 (strongly disagree).

\subsection{Methods of Data Analysis}

After the data had been gathered, a variety of tools were used to analyze it in order to capture the relevant findings and also present it in a manner that would be understood by fellow researchers and other research users. Editing was done in order to discard unwanted and irrelevant information, verify the data and check for consistency.

\subsection{Principal Component Analysis (PCA)}

The method of Principal Component Analysis (PCA) was used to establish the factors that influence SMEs choice of Microfinance Institutions consider when in municipality. This research constructs a set of variables, $\operatorname{COMPi}(i=1,2,3 \ldots, k)$ out of a set of variables $\mathrm{X} j(j=1,2,3 \ldots, k)$. The $C O M P i$ are simply linear combination of the 
$\mathrm{X} j$ 's;

$$
\begin{aligned}
\operatorname{COMP}_{1} & =a_{11} X_{1}+a_{12} X_{2}+a_{13} X_{3}+\ldots \ldots \ldots . .+a_{1 k} X_{k} \\
\operatorname{COMP}_{2} & =a_{21} X_{1}+a_{22} X_{2}+a_{23} X_{3}+\ldots \ldots \ldots . .+a_{2 k} X_{k} \\
\operatorname{COMP}_{1} & =a_{31} X_{1}+a_{32} X_{2}+a_{33} X_{3}+\ldots \ldots \ldots . .+a_{3 k} X_{k} \\
\operatorname{COMP}_{1} & =a_{41} X_{1}+a_{42} X_{2}+a_{43} X_{3}+\ldots \ldots \ldots . .+a_{4 k} X_{k} \\
\ldots \ldots . . & \\
\operatorname{COMP}_{k} & =a_{k 1} X_{1}+a_{k 2} X_{2}+a_{k 3} X_{3}+\ldots \ldots \ldots . .+a_{k k} X_{k}
\end{aligned}
$$

The $X_{j}$ 's represent a set of 15 variables which are postulated to influence SMEs choice of Microfinance Institution in LaNMMA. The alphas (a's) known as the loadings are computed so that a respective principal component satisfies two conditions: i) the $\operatorname{COMP}_{i}$ are orthogonal and ii) the first principal component account for the maximum proportion of total variations in all $\mathrm{X}_{\mathrm{j}}$ s. The second principal component absorbs the maximum of the remaining variations in the $X_{j}$ 's. $A$ is hypothesized to influence SME's choice of microfinance institutions in the Madina Municipality brief description of these variables are given below.

Table 1. List of Variables (X's)

\begin{tabular}{ccc}
\hline No & Variable $\left(\mathrm{X}_{\mathrm{j}^{\prime} \mathrm{S}}\right)$ & Description \\
\hline 1 & $\mathrm{X}_{1}$ & Experience \\
2 & $\mathrm{X}_{2}$ & Reputation \\
3 & $\mathrm{X}_{3}$ & BoG Registration \\
4 & $\mathrm{X}_{4}$ & External Appearance \\
5 & $\mathrm{X}_{5}$ & Proximity to home \\
6 & $\mathrm{X}_{6}$ & Proximity to workplace \\
7 & $\mathrm{X}_{7}$ & Security Arrangement \\
8 & $\mathrm{X}_{8}$ & Customer Service \\
9 & $\mathrm{X}_{9}$ & Speedy Service \\
10 & $\mathrm{X}_{10}$ & Parking facility \\
11 & $\mathrm{X}_{11}$ & Online Banking Service \\
12 & $\mathrm{X}_{12}$ & Phone Banking Service \\
13 & $\mathrm{X}_{13}$ & Availability of ATM \\
14 & $\mathrm{X}_{14}$ & Interest Rate on Loans \\
15 & $\mathrm{X}_{15}$ & Interest Rate on Savings \\
\hline
\end{tabular}

Source: Field data, 2018.

The task is to obtain the loadings, $a$ 's, which will transform the $\mathrm{X}_{\mathrm{j} \text { 's }}$ into artificial orthogonal variables known as components. The next task is to test whether the component loadings are statistically significant and subsequently decide how many principal components are to be retained in the analysis.

\subsubsection{Computation of Component Loadings}

The loadings for the principal component, $(a s)$, are obtained from a table of pairwise correlation of all the eleven $X_{j}$ variables using the formula;

$$
\mathrm{a}_{\mathrm{ij}}=\frac{\sum_{j}^{k} r_{x i x j}}{\sqrt{\sum_{j}^{k} \sum_{j}^{m} r_{x i x j}}}
$$

Where: $\mathrm{r}_{x i x j}$ represents the correlation coefficient between the $x_{i}$ and $x_{j}$ variables $\sum_{i}^{k} \sum_{j}^{m} r_{x i x j}$ represents the grand total of correlation coefficients across columns and rows of the correlation matrix. In this context, the loadings can be viewed as special forms of correlations among variables.

\subsubsection{Test of Significance of Component Loadings}

Several tests have been proposed to test the significance of component loadings. The first is the "empirical test". This is a crude measure of the significance of loadings. The rule of thumb with this approach is to consider factor loadings with absolute values of 0.35 or more as significant provided the number of observations exceeds 50 . The second test is based on the level of significance of the Pearson correlation coefficients since the factor loadings themselves are a form of correlation coefficients. Given that the sample for the study is 153 observations, the critical values of significant factor loadings are 0.15 at $5 \%$ level of significance and 0.255 at $1 \%$ level of significance. In this study, the empirical test threshold of 0.35 was employed in determining the significance of component loadings because the decision from this approach is consistent with that of the critical value of the correlation coefficient approach. 


\subsubsection{Criteria for Selecting the Principal Components}

A number of tests have emerged for selecting the ideal number of components in a PCA analysis. Two of them are discussed and used in this study. The first is the Kaiser (1958) criterion. The decision rule is to select only principal components with latent roots of eigen values greater than or equal to one. Let $\lambda_{m}$ be the $m$ th eigen value of the $m$ th component computed as follows:

$$
\lambda_{m}=\sum_{i}^{k} a_{m i}^{2}
$$

Kaiser's criterion simply states that retain $\operatorname{COMP}_{i}$ if $\lambda_{m}>1$. The second approach to selecting the ideal number of components is the use of Carttell $(1966,2012)$ scree plot. This criterion is simply a plot of the latent roots against the order of extracted components. The shape of the resulting curve is used to decide on the number of components to retain. The decision rule is to retain components up to the point where the resulting curve has some curvature and reject components for which the plot becomes a straight line. In this study, both Kaiser (1958) and Carttell (1966) tests were employed to determine the ideal number of components.

\section{Empirical Results and Discussions}

This section concentrates on the research analysis, findings and discussions of data on the factors that influence SME's. The profile of the respondents consisting of the age categories, income level education, gender; period of years was analyzed.

\subsection{Socio-Economic Demographic Characteristics of Respondent's}

The socio-economic demographic characteristics of the respondents are summarized in Table 1.

Table 2. Socio-economic demographic characteristics of respondents

\begin{tabular}{|c|c|c|c|}
\hline & & $\mathbf{N}$ & $\%$ \\
\hline \multirow[t]{3}{*}{ Gender } & Female & 156 & 55.9 \\
\hline & Male & 123 & 44.1 \\
\hline & Total & 279 & 100 \\
\hline \multirow[t]{7}{*}{ Age group } & Below 20 years & 41 & 14.7 \\
\hline & $21-40$ years & 180 & 64.5 \\
\hline & 41-60 years & 43 & 15.4 \\
\hline & Above 60 years & 15 & 5.4 \\
\hline & Total & 279 & 100.0 \\
\hline & Below JHS & 54 & 19.4 \\
\hline & JHS to SHS complete & 175 & 62.7 \\
\hline \multirow[t]{7}{*}{ Level of Education } & Diploma & 31 & 11.1 \\
\hline & Bachelor Degree & 17 & 6.1 \\
\hline & Masters & 1 & .4 \\
\hline & Others- specify & 1 & .4 \\
\hline & Total & 279 & 100.0 \\
\hline & Below GHC 500 & 175 & 62.7 \\
\hline & GHC 501-GHC 1000 & 63 & 22.6 \\
\hline \multirow[t]{6}{*}{ Income } & GHC 1001-GHC 1500 & 26 & 9.3 \\
\hline & GHC 1501-GHC 2000 & 12 & 4.3 \\
\hline & Above 2000 & 3 & 1.1 \\
\hline & Total & 279 & 100.0 \\
\hline & Less than 2 years & 99 & 35.5 \\
\hline & 2-4 years & 122 & 43.7 \\
\hline \multirow[t]{3}{*}{ Experience of SME's } & $5-7$ years & 40 & 14.3 \\
\hline & More than 7 years & 18 & 6.5 \\
\hline & Total & 279 & 100.0 \\
\hline
\end{tabular}

Source: Researcher's Field Data, 2018.

\subsection{Socio-Economic Demographic Characteristics of Respondent's}

Table 2 gives the statistical evidence of the gender distribution for the study. Apparently, 32 (64\%) of the respondents were males, while $18(36 \%)$ were females. The finding indicates that variably majority of the study respondents are males. Eerily, $68 \%$ majority of the respondents aged between $20-35$ years and only $32 \%$ are aged between 36-65 years. The study also explored the educational background of respondents and it has been portrayed that majority of $39(78 \%)$ as Post graduates. Doctorial graduates followed closely with $9(18 \%)$. 
Respondents with first degree holders secured 2(4\%). The study discovered that 39(78\%) of the respondents indicated that they were singles, whilst $11(22 \%)$ said they have married. This clearly shows that majority of the respondents were single. As shown in Table 2 above. In conclusion to the general background of the respondents, $18 \%$ (9) of the respondents indicated that they are Directors, another set of respondents 6\% (3) also expressed that they are supervisors. Out of the 50 respondents interviewed; 76\% (38) were workers as well. None of the respondents were Deputy Minister at the time this study was conducted.

\subsection{KMO and Bartlett's Test}

Table 3. KMO and Bartlett's test of sphericity

\begin{tabular}{lrr}
\hline \multicolumn{2}{l}{ Kaiser-Meyer-Olkin Measure of Sampling Adequacy } & .725 \\
\hline & Approx. Chi-Square & 1027.935 \\
Bartlett's Test of Sphericity & Df & 105 \\
\hline
\end{tabular}

Source: Researcher's Field Data, 2018.

According to Kaiser (1974), a minimum value of 0.5 for the KMO test is acceptable for a factor analysis to proceed. However, Hutcheson and Sofroniou (1999) indicated that statistics between 0.7 and 0.8 should be considered good, values between 0.8 and 0.9 should be considered "very good" and those above 0.9 should be considered excellent. The computed test statistics for this study is 0.725 which falls into the "good" classification. This indicates that the sample size is adequate for the factor analysis. The Bartlett's test of Sphericity is also significant at a $1 \%$ level thereby indicating that the null hypothesis of no correlation among the variables can be rejected. This implies that there are significant correlations for principal component analysis to proceed. Following the adequacy of the KMO and Bartlett tests the study proceeds with a principal component analysis of the variables to determine the number of factors that influence SME's the choice of microfinance institutions. Table 4, shows the extraction statistics. The latent root criterion or empirical test method used to identify the number of factors that influence SME's choice of a microfinance institution in the Municipality. An eigenvalue of 1 was set as the cut-off point. Factors or components with eigenvalues less than 1 are ignored.

\subsection{Principal Component Analysis}

The table below was generated by the Statistical Package for Social Sciences (SPSS) version 21. From the table 4 , there are five (5) factors selected for further analysis. This is confirmed by the scree plot figures in figure 1 as an attached appendix. These five principal components explain about $62.9 \%$ of the total variance. The extraction sum of squared loadings contained under the proportions column of table 3 presents the portion of variance explained by the respective components.

Table 4. Component table with total variance explained

\begin{tabular}{|c|c|c|c|c|c|c|c|c|c|}
\hline \multirow[t]{3}{*}{ Component } & \multicolumn{9}{|c|}{ Total Variance Explained } \\
\hline & \multicolumn{3}{|c|}{ Initial Eigenvalues } & \multicolumn{3}{|c|}{ Extraction Sums of Squared Loadings } & \multicolumn{3}{|c|}{ Rotation Sums of Squared Loadings } \\
\hline & Total & $\%$ of Variance & Cumulative $\%$ & Total & $\%$ of Variance & Cumulative \% & Total & $\%$ of Variance & Cumulative $\%$ \\
\hline 1 & 3.588 & 23.918 & 23.918 & 3.588 & 23.918 & 23.918 & 2.296 & 15.304 & 15.304 \\
\hline 2 & 1.957 & 13.048 & 36.966 & 1.957 & 13.048 & 36.966 & 2.063 & 13.756 & 29.061 \\
\hline 3 & 1.516 & 10.104 & 47.069 & 1.516 & 10.104 & 47.069 & 1.792 & 11.948 & 41.009 \\
\hline 4 & 1.236 & 8.243 & 55.312 & 1.236 & 8.243 & 55.312 & 1.761 & 11.737 & 52.746 \\
\hline 5 & 1.148 & 7.654 & 62.966 & 1.148 & 7.654 & 62.966 & 1.533 & 10.221 & 62.966 \\
\hline 6 & .905 & 6.033 & 68.999 & & & & & & \\
\hline 7 & .775 & 5.166 & 74.165 & & & & & & \\
\hline 8 & .718 & 4.790 & 78.955 & & & & & & \\
\hline 9 & .615 & 4.098 & 83.053 & & & & & & \\
\hline 10 & .555 & 3.702 & 86.755 & & & & & & \\
\hline 11 & .508 & 3.386 & 90.141 & & & & & & \\
\hline 12 & .455 & 3.032 & 93.174 & & & & & & \\
\hline 13 & .399 & 2.663 & 95.837 & & & & & & \\
\hline 14 & .357 & 2.381 & 98.217 & & & & & & \\
\hline 15 & .267 & 1.783 & 100.000 & & & & & & \\
\hline Extraction $\mathrm{M}$ & od: $\operatorname{Pr}$ & ipal Compone & Analysis. & & & & & & \\
\hline
\end{tabular}


Appendix A indicates the scree plot figure as the graphical representation of the total eigenvalues against the components. The only difference is that of the latent root or empirical test for determining the significance of the component loadings has been applied in table 3. The results of this transformation leave us with a component table with several cross-loadings which make distinct interpretation of component nearly impossible.

A significant majority of the variables in the study loaded on either principal component 1 and 2 with very few loadings onto the other 3 remaining components. This turnout of event blurred the distinct lines between the components thereby making interpretation very difficult. In view of the difficulty with the unrotated factor matrix, a PROMAX rotation was applied to help deal with the problems of cross-loadings. The results of this loadings are presented in Table 5 below.

Table 5. Rotated component matrix

\begin{tabular}{|c|c|c|c|c|c|}
\hline \multicolumn{6}{|c|}{ Rotated Component Matrix $^{\mathrm{a}}$} \\
\hline & \multicolumn{5}{|c|}{ Component } \\
\hline & 1 & 2 & 3 & 4 & 5 \\
\hline The online banking service & .838 & & & & \\
\hline The phone banking service & .768 & & & & \\
\hline The parking facilities of MFI & 679 & & & & \\
\hline The availability of ATM & .653 & & & & \\
\hline The proximity of MFI to home & & .818 & & & \\
\hline The proximity of MFI to workplace & & .755 & & & \\
\hline The external appearance of the MFI & & .690 & & & \\
\hline The experience of the MFI & & & .740 & & \\
\hline The reputation of the MFI & & & .736 & & \\
\hline The MFI registered by Bank of Ghana & & & .639 & & \\
\hline The low interest rate on loans & & & & .888 & \\
\hline The high interest rate on savings & & & & .881 & \\
\hline The quality of customer service provided by MFI & & & & & .757 \\
\hline The MFI speedy service & & & & & .742 \\
\hline The security arrangement of the MFI & & & & & .524 \\
\hline \multicolumn{6}{|l|}{ Extraction Method: Principal Component Analysis. } \\
\hline Rotation Method: Promax & & & & & \\
\hline
\end{tabular}

a. Rotation converged in 6 iterations.

Table 5 above shows the results of the PROMAX rotation. The major problems that confronted us with regards to the unrotated factor matrix-matrix have been mitigated considerably. The rotation still maintains the 5 components with no cross-loadings that will impair the naming of these components. In addition, the factor loadings have been spread relatively more evenly over the components that we had in the unrotated matrix. In the next paragraph, we name these components appropriately according to the variable that loaded onto them. Table 6 below presents the names assigned to each factor on the basis of their factor loadings in Table 5 .

Table 6. Names of principal components

\begin{tabular}{ll}
\hline Principal Components & Names \\
\hline 1 & Electronic Banking (EB) \\
2 & Convenience and Security \\
3 & Reputation and Legal regulation \\
4 & Interests Rate \\
5 & Service Provided \\
\hline
\end{tabular}

Source: Researcher's Field Data, 2018.

\section{Component 1: Electronic Banking}

The first principal component that influences SME's choice of microfinance institutions in LaNMMA is labelled as Electronic Banking (EB) This principal component has an eigenvalue of 3.5 and accounts for about $23.92 \%$ of total variations in all the variables. The component has four (4) variables loading significantly onto it in the rotated component table. These variables focus on the Electronic Banking reasons that may compel SMEs choice of microfinance institutions. E-banking enables the financial institution to deliver its service easily to its high-end customers, to make the system user friendly to all SMEs, $83.8 \%$ of the respondents agree to the use of 
online banking service, $76.8 \%$ prefer phone banking services, $65.3 \%$ of the respondent agreed that availability of ATM in MFI influence their choice of MFI.

\section{Component 2: Convenience and Security}

The second principal component is named Convenience and Security. This component has an eigenvalue of 1.95 and accounted for $13.05 \%$ of total variations in the variables. This component like the preceding one also has three (3) variables loading onto it significantly. $81.8 \%$ agree to proximity to home, $75.5 \%$ agreed to proximity to the workplace and $69 \%$ of the respondents agreed that these variables influence SMEs choice of MFIs.

\section{Component 3: Reputation and Legal regulation}

This principal component had an eigenvalue of 1.51 and accounted for $10.10 \%$ of the total variations in the variables. The component has three (4) variables loading unto it significantly. These variables focus on the reputation and legal regulation reasons that may compel SMEs choice of microfinance institutions. $74 \%$ of the respondents agreed to the experience of the MFI, 73.6\% agreed to the reputation of the MFI and $63.9 \%$ trusted that MFIs registered by Bank of Ghana influence SMEs choice of MFIs.

\section{Component 4: Interest Rate}

This principal component had an eigenvalue of 1.24 and accounted for $8.24 \%$ of the total variations in the variables. The component has two (2) variables loading unto it significantly. This variable focus on interest, $88.1 \%$ of the respondents agreed that higher interest rate on savings will influence SMEs choice of microfinance and $88.8 \%$ of the respondents trusted that low-interest rate on loans will influence SMEs choice of microfinance.

\section{Component 5: Service Provided}

This principal component had an eigenvalue of 1.15 and accounted for $7.7 \%$ of the total variations in the variables. The component has three (3) variables loading unto it significantly. Microfinance institution needs to have qualified staff members on the hand that are regularly available to perform the service that it offers to consumers. $75.5 \%$ of the respondents agreed to the quality of customer service provided by MFI,74.2\% also agreed to the MFIs speedy service and 52.4\% agreed that security arrangement of MFI will influence SMEs choice of microfinance institution.

\section{Discussion}

The study found out that the first influential factor that serves as a choice for SME's is electronic banking. This was closely followed by convenience and security of the MFI's. The third considerable factor was the reputation and legal regulation of MFI's which is not obvious since there is a rampant collapsing of MFI's recently. This was also followed by the interest rate and services provided by the MFI's. The findings of the first component named as electronic banking accentuates with studies conducted in Singapore, Lahore in Pakistan, Malaysia, and Gambia by Ta and Har (2000); Rehman and Ahmed (2008); Mokhlis et al. (2009); Manarvi (2009) and Sanvang et al. (2009) respectively. It implies that the 21 st-century syndrome of information era must be welcome in most financial institutions that want to survive in the competitive environment. Similar to the second component thus, convenience and security which is also in line with studies carried out by Kumar et al. (2009), Farooq et al. (2010) and Maiyaki (2011). This implies that a microfinance location nearby to customers and with a good security system will lure SME's or other potential customers to choose that institution to transact his or her business rather than its competitors that are out of reach. The rest of the findings are also in relation to the findings of Katircioglu et al. (2011); Shaher et al. (2011); Abduh et al. (2010); and Rao (2010).

\section{Conclusion and Policy Recommendations}

The primary focus was on factors that influence SME's choice of a microfinance institution in LaNMMA and also determine the factors that SMEs consider to be important when choosing a Microfinance and how those criterions are prioritized according to their importance. SMEs are concerned about the security of their investments when the degree of bank security is higher the probability of choosing a bank by customers will be higher. Five out of the fifteen constructs in the study had a positive association with SMEs choice of microfinance institutions. However, the first and second of these five are electronic banking and convenience and security. Finally, the study concludes that the reputation of a business is also essential to its survival, the trust and confidence of the SME can have a direct and profound effect on microfinance institutions. The study recommended that, microfinance institutions should make it a must to obtain all necessary banking licenses from Bank of Ghana before they commence business in order to avoid the embodiment of fear of collapse into potential SME's who might be willing to transact business with them and also educate those who render services on behalf of the bank. Customer service is very important and should be considered as the first priority of the 
bank.

\section{References}

Abduh, M., \& Omar, M. A. (2010). Who patronizes Islamic banks in Indonesia? Australian Journal of Islamic Law, Management and Finance, 1(1), 46-53.

Aregbeyen, O. (2011). The Determinants of Bank Chosen Choices by Customers: Recent and Extensive Evidence from Nigeria. International Journal of Business and Social Science, 2(22).

Asiama, J. P., \& Osei, V. (2007). Microfinance in Ghana: An overview. Accra, Ghana: Research Department, Bank of Ghana.

Barney, J. (1991). Firm resources and sustained competitive advantage. Journal of Management, 17(1), 99-120. https://doi.org/10.1177/014920639101700108

Blankson, C., Ming-Sung, C. J., \& Spears, N. (2007). Determinants of banks selection in USA, Taiwan and Ghana. International Journal of Bank Marketing, 25(7), 469-489. https://doi.org/10.1108/02652320710832621

Cattell, R. (Ed.). (2012). The scientific use of factor analysis in behavioral and life sciences. Springer Science \& Business Media

Coombs, W. T. (2007). Protecting organization reputations during a crisis: The development and application of situational crisis communication theory. Corporate Reputation Review, 10(3), 163-176. https://doi.org/10.1057/palgrave.crr.1550049

Farooq et al. (2010). Biosorption of heavy metal ions using wheat based biosorbents-a review of the recent literature. Bioresource Technology, 101(14), 5043-5053. https://doi.org/10.1016/j.biortech.2010.02.030

Gerrard, P., \& Barton Cunningham, J. (1999). The multiple banking behaviour of Singaporeans. International Journal of Bank Marketing, 17(1), 26-35. https://doi.org/10.1108/02652329910254028

Godden, B. (2004). Sample size formulas.

Harvie, C., \& Lee, B. C. (Eds.). (2005). Sustaining growth and performance in East Asia: The role of small and medium sized enterprises (Vol. 3). Edward Elgar Publishing. https://doi.org/10.4337/9781845425630

Hinson, R. E., Osarenkhoe, A., \& Okoe, A. F. (2013). Determinants of Bank Selection: A Study of Undergraduate Students in the University of Ghana.

Hutcheson, G. D., \& Sofroniou, N. (1999). The multivariate social scientist: Introductory statistics using generalized linear models. Sage. https://doi.org/10.4135/9780857028075

Idowu, P. A., Alu, A. O., \& Adagunodo, E. R. (2002). The effect of information technology on the growth of the banking industry in Nigeria. The Electronic Journal of Information Systems in Developing Countries, 10(1), 1-8. https://doi.org/10.1002/j.1681-4835.2002.tb00060.x

Jones, M. A., Mothersbaugh, D. L., \& Beatty, S. E. (2000). Switching barriers and repurchase intentions in services. Journal of retailing, 76(2), 259-274. https://doi.org/10.1016/S0022-4359(00)00024-5

Kaiser, H. F. (1958). The varimax criterion for analytic rotation in factor analysis. Psychometrika, 23(3), 187-200. https://doi.org/10.1007/BF02289233

Katircioglu, S. T., Tumer, M., \& Kilinç, C. (2011). Bank selection criteria in the banking industry: An empirical investigation from customers in Romanian cities. African Journal of Business Management, 5(14), 5551. https://doi.org/10.5897/AJBM11.408

Khan, M. S. N., Hassan, M. K., \& Shahid, A. I. (2007). Banking behavior of Islamic bank customers in Bangladesh. Journal of Islamic Economics, Banking and Finance, 3(2), 159-194.

Khawaja, K. F., \& Manarvi, I. (2009). Evaluating customer perceptions towards ATM services in financial institutions; A case study of Pakistani Banks. In International Conference on Computers \& Industrial Engineering (CIE 2009) (pp. 1440-1445). https://doi.org/10.1109/ICCIE.2009.5223706

Kumar, M., Tat Kee, F., \& Taap Manshor, A. (2009). Determining the relative importance of critical factors in delivering service quality of banks: An application of dominance analysis in SERVQUAL model. Managing Service Quality: An International Journal, 19(2), 211-228. https://doi.org/10.1108/09604520910943198

Mabin, V. J., \& Balderstone, S. J. (2003). The performance of the theory of constraints methodology: Analysis and discussion of successful TOC applications. International Journal of Operations \& Production 
Management, 23(6), 568-595. https://doi.org/10.1108/01443570310476636

Maiyaki, A. A. (2011). Factors determining bank's selection and preference in Nigerian retail banking. International Journal of Business and Management, 6(1), 253-257.

Mokhlis, S., Salleh, H. S., \& Mat, N. H. N. (2009). Commercial bank selection: Comparison between single and multiple bank users in Malaysia. International Journal of Economics and Finance, 1(2), 263. https://doi.org/10.5539/ijef.v1n2p263

Mugenda, O. M. (1999). Research methods: Quantitative and qualitative approaches. African Centre for Technology Studies.

Nguyen, N., \& LeBlanc, G. (1998). The mediating role of corporate image on customers' retention decisions: An investigation in financial services. International Journal of Bank Marketing, 16(2), 52-65. https://doi.org/10.1108/02652329810206707

Okoe, A. F., Osarenkhoe, A., \& Hinson, R. (2013). Using the analytical hierarchy process framework to study bank selection criteria of students in Institute of Professional Studies in Ghana. Journal of Strategy and Management., 4(3), 27-37.

Owusu-Frimpong, N. (1999). Patronage behaviour of Ghanaian bank customers. International Journal of Bank Marketing, 17(7), 335-342. https://doi.org/10.1108/02652329910305698

Phuong Ta, H., \& Yin Har, K. (2000). A study of bank selection decisions in Singapore using the analytical hierarchy process. International Journal of Bank Marketing, 18(4), 170-180. https://doi.org/10.1108/02652320010349058

Rao, S., \& Sharma, D. R. (2010). Bank selection criteria employed by MBA students in Delhi: An empirical analysis. https://doi.org/10.2139/ssrn.1597902

Rehman, H. U., \& Ahmed, S. (2008). An empirical analysis of the determinants of bank selection in Pakistan: A customer view. Pakistan Economic and Social Review, 147-160. https://www.jstor.org/stable/25825333

Sanyang, S. E., Kao, T. C., \& Huang, W. C. (2009). The impact of agricultural technology transfer to women vegetable production and marketing groups in the Gambia. World Journal of Agricultural Sciences, 5(2), 169-179.

Simanowitz, A., \& Brody, A. (2004). Realising the potential of microfinance. Insights, 51(1), 1-2.

Singh, S. P., \& Agarwal, T. (2016). Determinants of Bank Selection: A Study of Retail Banking Consumers in Gwalior. Journal of Applied Management-Jidnyasa, 8(1), 9-17.

Suganthi, B. (2001). Internet banking patronage: An empirical investigation of Malaysia.

Yunus, M. (2003). Banker to the poor: The story of the Grameen Bank. Aurum Press Limited.

Zineldin, M. (1996). Bank strategic positioning and some determinants of bank selection. International Journal of Bank Marketing, 14(6), 12-22. https://doi.org/10.1108/02652329610130136

\section{Appendix A}

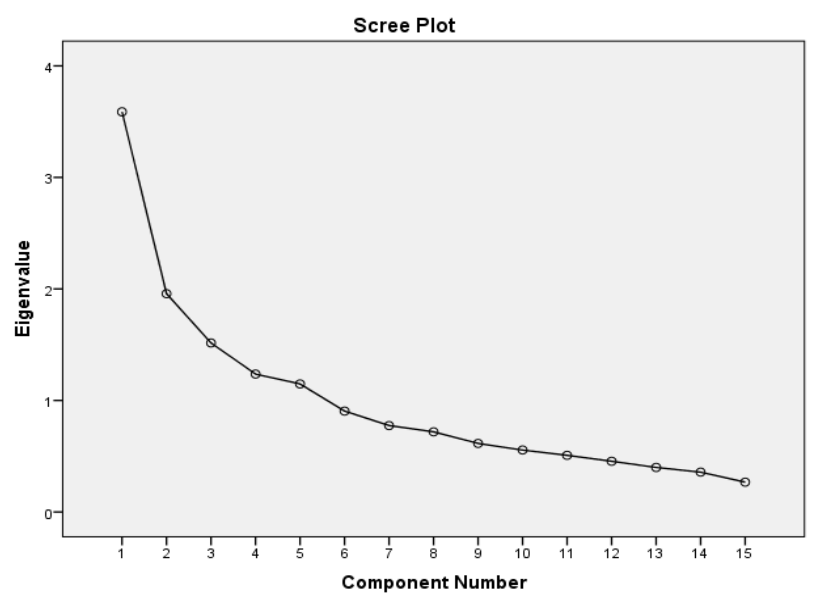

Figure A1. Scree plot of Eigenvalues after PCA 


\section{Appendix B}

\begin{tabular}{|c|c|c|c|c|c|}
\hline \multicolumn{6}{|c|}{ Component Matrix $^{\mathrm{a}}$} \\
\hline & \multicolumn{5}{|c|}{ Component } \\
\hline & 1 & 2 & 3 & 4 & 5 \\
\hline The online banking service & .627 & & -.568 & & \\
\hline The phone banking service & .604 & & -.469 & & \\
\hline The availability of ATM & .601 & & -.369 & & \\
\hline The experience of the MFI & .561 & & & -.426 & .336 \\
\hline The reputation of the MFI & .557 & & & & .374 \\
\hline The parking facilities of MFI & .529 & .451 & -.330 & & \\
\hline The proximity of MFI to workplace & .492 & .477 & .358 & & \\
\hline The security arrangement of the MFI & .457 & & & .353 & \\
\hline The low interest rate on loans & .465 & -.581 & & & -.490 \\
\hline The proximity of MFI to home & .330 & .555 & .480 & & \\
\hline The external appearance of the MFI & .410 & .519 & & & \\
\hline The MFI speedy service & & & & .665 & \\
\hline The quality of customer service provided by MFI & .421 & -.333 & & .450 & .353 \\
\hline The high interest rate on savings & .511 & -.474 & & & -.511 \\
\hline The MFI registered by Bank of Ghana & .347 & -.351 & & & .405 \\
\hline
\end{tabular}

\section{Copyrights}

Copyright for this article is retained by the author(s), with first publication rights granted to the journal.

This is an open-access article distributed under the terms and conditions of the Creative Commons Attribution license (http://creativecommons.org/licenses/by/4.0/). 